\title{
Responses of Two Apiaceae Species to Direct Iron Deficiency
}

\author{
Haifa Sbai*, Rabiaa Haouala \\ Department of Biological Sciences and Plant Protection, Higher Institute of Agronomy of Chott Meriem, Sousse, Tunisia
}

Email address:

haifa.sbai@yahoo.fr (H. Sbai), rabiahhaouala@gmail.com (R. Haouala)

${ }^{*}$ Corresponding author

\section{To cite this article:}

Haifa Sbai, Rabiaa Haouala. Responses of Two Apiaceae Species to Direct Iron Deficiency. International Journal of Photochemistry and Photobiology. Vol. 2, No. 1, 2018, pp. 16-21. doi: 10.11648/j.ijpp.20180201.14

Received: July 22, 2018; Accepted: August 8, 2018; Published: September 10, 2018

\begin{abstract}
The aim of this study was to investigate the morphological and physiological responses of Petroselinum crispum and Apium graveolens to iron deficiency. Seedlings of both species were cultivated in continuously aerated nutrient solution with or without $48.8 \mu \mathrm{M}$ Fe during one month. Score chlorosis, growth parameters, chlorophyll content, acidification capacity and iron, zinc and copper levels, were measured. The results showed that growth of both species was severely affected by direct iron deficiency. Nevertheless, chlorosis symptoms were more severe in P. crispum, compared to A. graveolens. High chlorosis index and a significant decrease of chlorophyll content were registered in $P$. crispum. In addition, shoot length and whole plant biomass production were affected by iron deficiency in both species. The lower reduction was observed in Fedeficient plants of $A$. graveolens. However, the later specie registered the highest root length. Moreover, a capacity of root acidification due to a noticeable proton release rate was observed with A. graveolens. Although grown under Fe deficiency conditions, these specie was able to increase their shoot iron use efficiency. Furthermore, Fe deficiency led to a significant accumulation of zinc in leaves of both species while copper accumulation was only noted in P.crispum roots. The capacity of A. graveloens to maintain plant growth and to preserve adequate chlorophyll synthesis under iron-limiting conditions is related to its better Fe-use efficiency, in addition to its high acidification and root reducing capacities. This allows us to suggest that $A$. graveolens is more effective to overcome iron deficiency than P. crispum.
\end{abstract}

Keywords: Petroselinum crispum, Apium graveolens, Fe Deficiency, Acidification Capacity, Iron Status, Chlorophyll Concentration

\section{Introduction}

Iron $(\mathrm{Fe})$ is the fourth most abundant element in the earth's crust and is essential for both plant growth and crop yield and most importantly, humans rely on dietary iron from plant sources. Despite its presence in large quantities in most soils, iron chemical forms are not available for plants and approximately $30 \%$ of the arable soils are iron deficient on Earth. In addition to its role in limiting plant growth, iron deficiency is the current most common human nutritional disorder in the world today. As most people get their iron from eating plants, understanding the mechanisms of how plants sense and respond to Fe availability is of interest for addressing agricultural problems and iron malnutrition of humans. To cope with this problem, plants have developed different adaptive mechanisms to increase Fe mobility and its uptake in the cytosol [1]. Dicotyledonous and non graminaceous monocots, termed Strategy I plants, respond to Fe deficiency by inducing a set of physiological mechanisms to boost $\mathrm{Fe}$ mobilization and uptake from soils [1], principally decreased the rhizosphere $\mathrm{pH}$, enhanced $\mathrm{Fe}^{3+}$ reduction capacity in roots, and increased root branching and hair formation [2-3]. In strategy II used by graminaceous plants, $\mathrm{Fe}$ acquisition is mediated by a chelation-based mechanism: produces molecules of the mugineic acid family called phytosiderophores (PS) secreted into the rhizosphere where they chelate and help to solubilise $\mathrm{Fe}^{3+}$, then the complex Fe (III)-PS absorbed by the root cells. To reduce iron chlorosis, several techniques such as foliar sprays and Fe-EDDHA seed treatment were employed [4-5] but they seem highly costing and do not always improve the Fenutrition of the plants [6]. Thus, selecting Fe-efficient genotypes could be an alternative approach [6] and remains 
the most practical solution for the agricultural losses caused by iron deficiency.

The aim of the current work was to assess the variability of tolerance of two apiaceae species (Petroselinum crispum and Apium graveolens) commonly cultivated in Tunisia. The morphological traits and physiological responses such as plant growth, chlorophyll content, root acidification capacity and interaction between $\mathrm{Fe}, \mathrm{Zn}$, and $\mathrm{Cu}$ in all plant organs, were investigated.

\section{Materials and Methods}

\subsection{Plant Materiel and Growth Conditions}

Seeds of $P$. crispum and A. graveolens were surface sterilized with $0.52 \mathrm{~g} / \mathrm{L}$ sodium hypochlorite for $15 \mathrm{~min}$ and then rinsed four times with deionized water. Seeds were sown in Petri dishes on filter paper moistened with distilled water for one week. After a pre-treatment in a half strength aerated nutrient solution diluted 4 fold during 7 days, similar sized seedlings were selected and divided into two lots and subjected to the different treatments. The growth medium was a complete half-strength Hoagland's nutrient solution [7]. Two treatments were established for 30 days as follows: control (addition of $\mathrm{Fe}$ at $48.8 \mu \mathrm{M}$ : $\mathrm{C}$ ) and direct iron deficiency. The composition of the nutrient solution was: $2.5 \mathrm{mM} \mathrm{Ca}\left(\mathrm{NO}_{3}\right)_{2}, 3 \mathrm{mM} \mathrm{KNO}_{3}, 1 \mathrm{mM} \mathrm{MgSO} 4,1 \mathrm{mM}$ $\mathrm{KH}_{2} \mathrm{PO}_{4}, 20 \mu \mathrm{M} \mathrm{H}_{3} \mathrm{BO}_{3}, 2 \mu \mathrm{M} \mathrm{MnSO}_{4}, 1 \mu \mathrm{M} \mathrm{ZnSO}_{4}, 0.1 \mu \mathrm{M}$ $\left(\mathrm{NH}_{4}\right)_{6} \mathrm{Mo}_{7} \mathrm{O}_{24}$ and $1 \mu \mathrm{M} \mathrm{CuSO}$. The controlled climatic conditions were the following: day/night photoperiod of 14/10h; temperature (day/night) $24 / 18^{\circ} \mathrm{C}$; light intensity, 5000 lux and a relative humidity of $60 \%$. Nutrient solution $(\mathrm{pH}=6.0)$ was weekly renewed. Iron solutions (Fe-EDTA) were prepared following Jacobson's method [8]. All plants used for the determination of the measured parameters measured were randomly selected from the different containers of each treatment.

\subsection{Determination of the Chlorosis Index}

The visual chlorosis symptoms is performed using the nondestructive index (or score) proposed by Gildersleeve and Ocumpaugh [9]: (0) green young leaves, (1) slight chlorosis with specific yellow leaf margins, (2) yellow limb with green mid-vein, (3) completely yellow leaves and (4) largely necrotic leaves. A number was attributed to each plant according to the chlorotic state of its young leaves and, a mean of 24 replicates was calculated for each treatment.

\subsection{Determination of Photosynthetic Pigments Content}

The chlorophyll and carotenoid concentrations $\left(\mathrm{mg} \mathrm{g}^{-1}\right.$ FW) of young leaves were determined according to the method of Torrecilas et al. [10]. One hundred milligrams of small discs from young leaves were incubated in $5 \mathrm{ml} 80 \%$ acetone in darkness at $4^{\circ} \mathrm{C}$ during $72 \mathrm{~h}$, until complete chlorophyll extraction. The extract absorbance was measured at $665 \mathrm{~nm}, 649 \mathrm{~nm}$ and $470 \mathrm{~nm}$.

\subsection{Nutrient Extraction and Analysis}

At the harvested day, plants were separated into shoots and roots. Roots were washed with $1 \%(\mathrm{v} / \mathrm{v}) \mathrm{HCl}$ in order to remove extracellular $\mathrm{Fe}$, then rinsed several times with distilled water. Mineral nutrients were extracted following the method described by Zorrig et al. [11]: $50 \mathrm{mg}$ of the sample were digested with $30 \mathrm{ml}$ of sulfuric acid (20\%). The mixture was incubated during one hour at $80^{\circ} \mathrm{C}$ and agitated every 10 minutes then kept at ambient temperature for one night. Samples were analyzed for micronutrient (Fe, $\mathrm{Zn}$ and $\mathrm{Cu}$ ) using an Atomic Absorption Spectrophotometer (VARIAN 220 FS).

\subsection{Root Acidification}

During the final 10 days, a follow-up of the culture medium $\mathrm{pH}$ of each container was realized by measuring the $\mathrm{pH}$ every two days with a Radiometer PHM 84 pH meter.

\subsection{Biomass Production in Shoots and Roots}

After 30 days of treatment, plants were harvested and separated into leaves, stems and roots. Roots were briefly rinsed with distilled water. Root and shoot dry weights were determined after drying at $70^{\circ} \mathrm{C}$ for $72 \mathrm{~h}$.

\subsection{Statistical Analysis}

Statistical analysis was performed using the SPSS 20.0 program. Means were separated according to Duncan's test at $\mathrm{P} \leq 0.05$. Data shown are means of twenty four (for chlorosis index), four (for nutrient analysis) and eight (for leaves number, shoot and root length, acidification capacity, plant dry weight and chlorophyll) replicates for each treatment.

\section{Results}

\subsection{Chlorosis Index and Chlorophyll Status}

At the end of the experimental period, plants grown on iron deficient medium for both species clearly showed chlorosis symptoms. Nevertheless, these symptoms appeared earlier in young leaves of $P$. crispum. Indeed, chlorosis symptoms were noted from the fourth day of treatment and the chlorosis index was significantly higher (reaching 2) for P. crispum, compared to A. graveolens (maximum 1.38) (Figure 1). Additionally, Fe deficiency led to a significant decrease of the chlorophyll content for both species. The reduction rate was lower in deficient plants of $A$. graveolens, ranging from 40 to $44 \%$ compared to the control, for chla and chlb, respectively. By contrast, in P. crispum, the chla and chlb content decreased by 50 and $73 \%$, respectively. No significant impact was noted for the content of carotenoids in the latter, whereas in the former, their level was reduced by $50 \%$ of the control (Figure 2). 

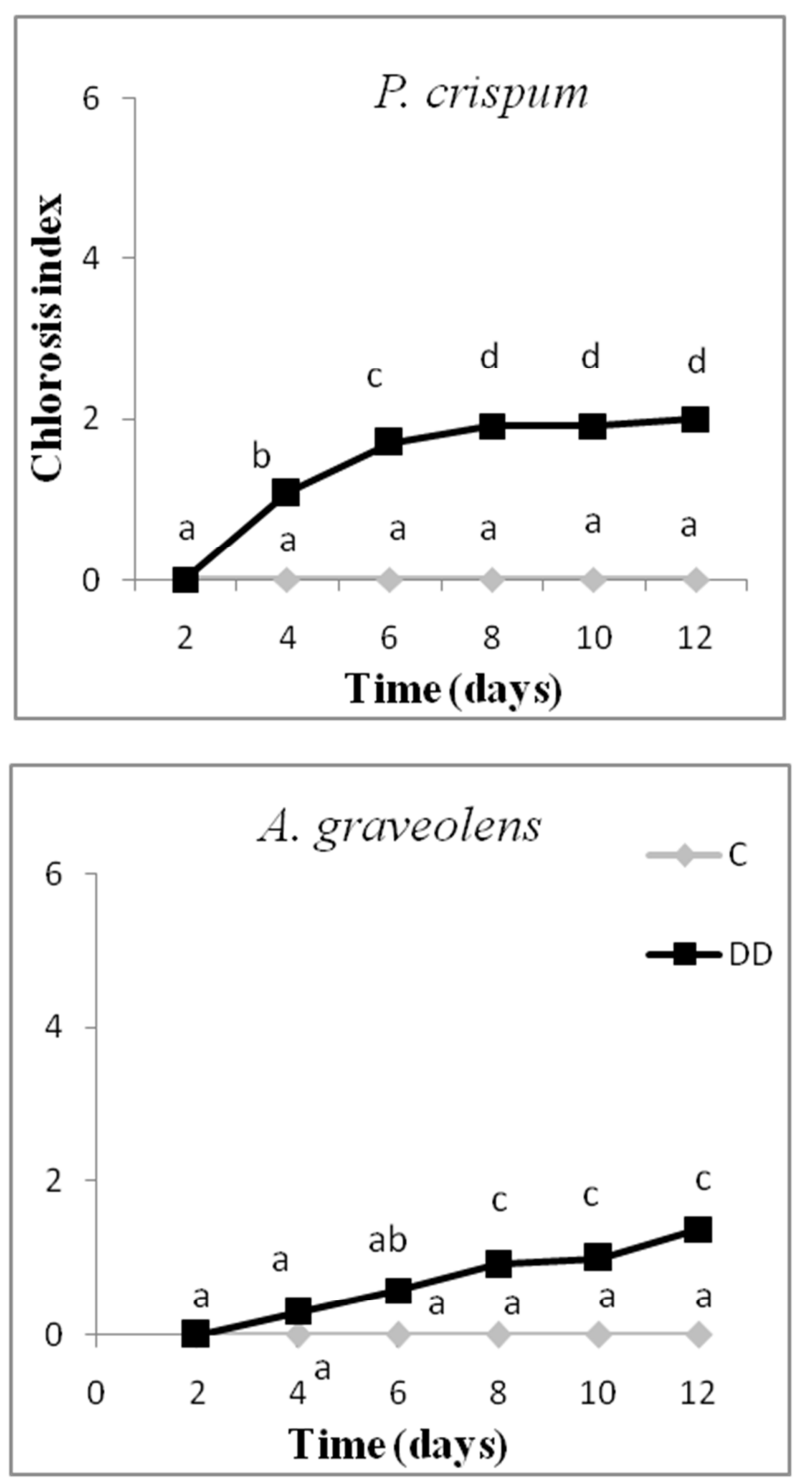

Figure 1. Chlorosis index according to Gildersleeve and Ocumpaughscale in young leaves of P. crispum and A. graveolens cultivated with or without $48.8 \mu M$ Fe during 12 days. Different letters correspond to significantly different values at $(P<0.05, n=24)$.
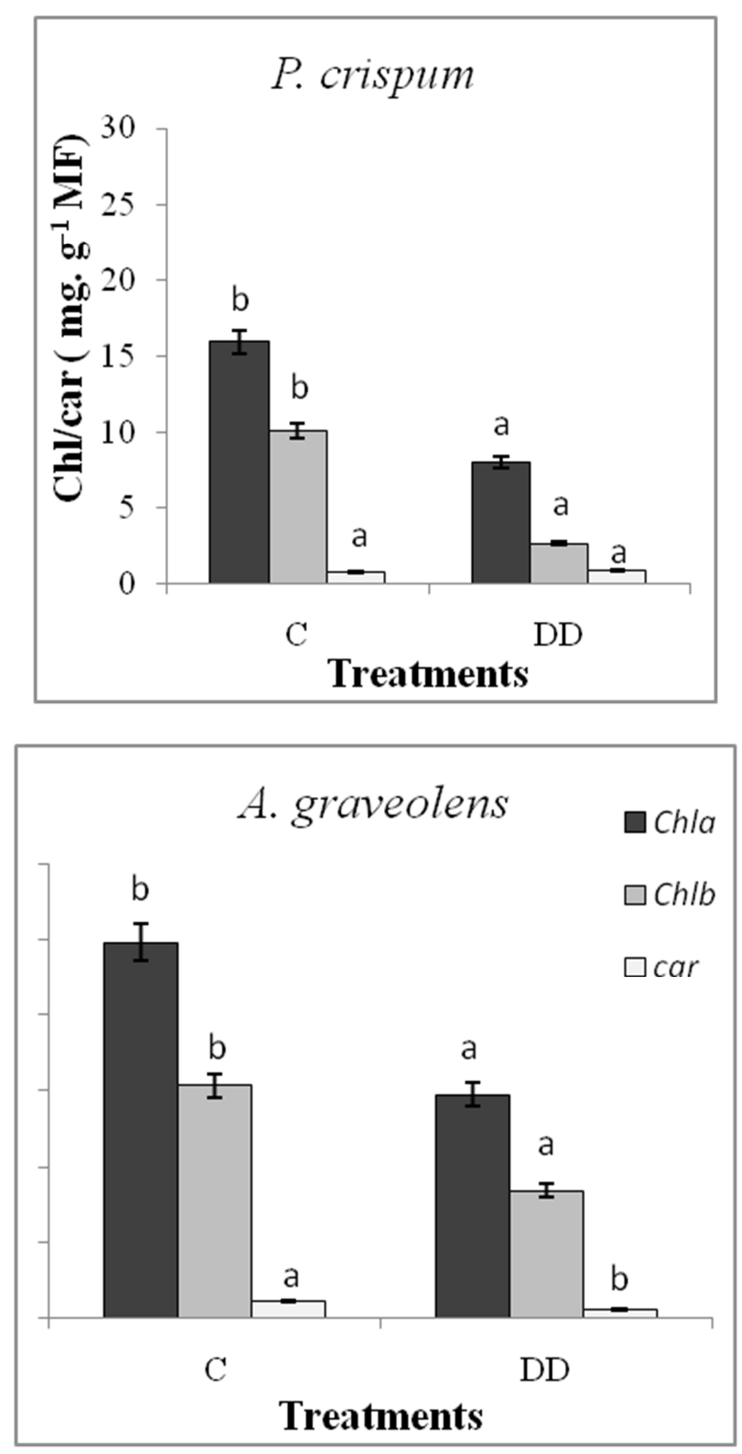

Figure 2. Chlorophyll and carotenoid content of the young leaves of $P$. crispum and A. graveolens grown during 30 days on a control nutrient solution (C), containing $48.8 \mu \mathrm{MFe}$, or under direct iron deficiency (DD). Values are means of 8 replicates \pm standard deviation. Different letters correspond to significantly different values at $P<0.05$.

\subsection{Plant Growth}

Table 1. Plant growth in P. crispum and A. graveolens grown during one month on a control nutrient solution containing 48.8 $\mu M$ Fe (C: control) or in the absence of $\mathrm{Fe}$ (DD: direct deficiency).

\begin{tabular}{|c|c|c|c|c|}
\hline Species & P. crispum & & A. graveolens & \\
\hline Treatments & $\mathrm{C}$ & DD & $\mathbf{C}$ & DD \\
\hline Leaves number & $48.37 \pm 9.16^{b}$ & $31.87 \pm 4.76^{\mathrm{a}}$ & $42.25 \pm 4.43^{\mathrm{a}}$ & $41.75 \pm 5.14^{a}$ \\
\hline Shoot length (cm) & $38.71 \pm 3.18^{\mathrm{a}}$ & $34.78 \pm 4.47^{\mathrm{a}}$ & $55.55 \pm 3.35^{\mathrm{a}}$ & $45.43 \pm 5.72^{b}$ \\
\hline Root length (cm) & $20.68 \pm 2.34^{\mathrm{a}}$ & $25.08 \pm 8.35^{\mathrm{ab}}$ & $27.71 \pm 6.48^{\mathrm{ab}}$ & $35.87 \pm 8.52^{c}$ \\
\hline Leaves DW (g) & $3.49 \pm 0.66^{\mathrm{b}}$ & $0.98 \pm 0.21^{\mathrm{a}}$ & $2.22 \pm 0.55^{\mathrm{b}}$ & $1.81 \pm 0.25^{\mathrm{a}}$ \\
\hline Stem DW $(\mathrm{g})$ & $2.8 \pm 0.58^{b}$ & $0.93 \pm 0.16^{\mathrm{a}}$ & $2.59 \pm 0.40^{\mathrm{b}}$ & $2.06 \pm 0.29^{\mathrm{a}}$ \\
\hline Root DW (g) & $1.72 \pm 0.58^{\mathrm{b}}$ & $0.53 \pm 0.19^{\mathrm{a}}$ & $1.08 \pm 0.11^{\mathrm{a}}$ & $0.91 \pm 0.11^{\mathrm{a}}$ \\
\hline
\end{tabular}

Different letters correspond to significantly different values at $(\mathrm{p}<0.05)$ according to Duncan test.

The -Fe treatment reduced significantly the number of leaves per plant by $35 \%$ in $P$. crispum, compared to the control, however no change was noted in $A$. graveolens. Iron deficiency has induced $10 \%$ to $18 \%$ reduction of the shoot length, relative to control for P. crispum and A. graveolens, respectively. For roots, a significant increase of their length 
was registered $(21.27 \%$ and $29.44 \%$ increase, respectively for P. crispum and A. graveolens) (Table 1). The overall growth of plants was markedly restricted by iron deficiency. However, significant differences were observed between species. P. crispum was characterized by the sharpest decrease for all plant parts. Leaves and roots were the most affected plant parts. Their biomass was reduced, respectively, by $72 \%$ and $69 \%$ of the control. By contrast, in $A$. graveolens, an average reduction of $18 \%$ was registered for whole plant parts (Table 1).

\subsection{Root Acidification Capacity}

The $\mathrm{pH}$ of the culture medium was measured every two days during the last eight days of treatment and values were represented in Figure 3. An acidification of the medium occurred in the absence of $\mathrm{Fe}$ in all cases. However, with $A$. graveolens, the values were the lowest, reaching $3.5 \mathrm{pH}$ unit (Figure 3).
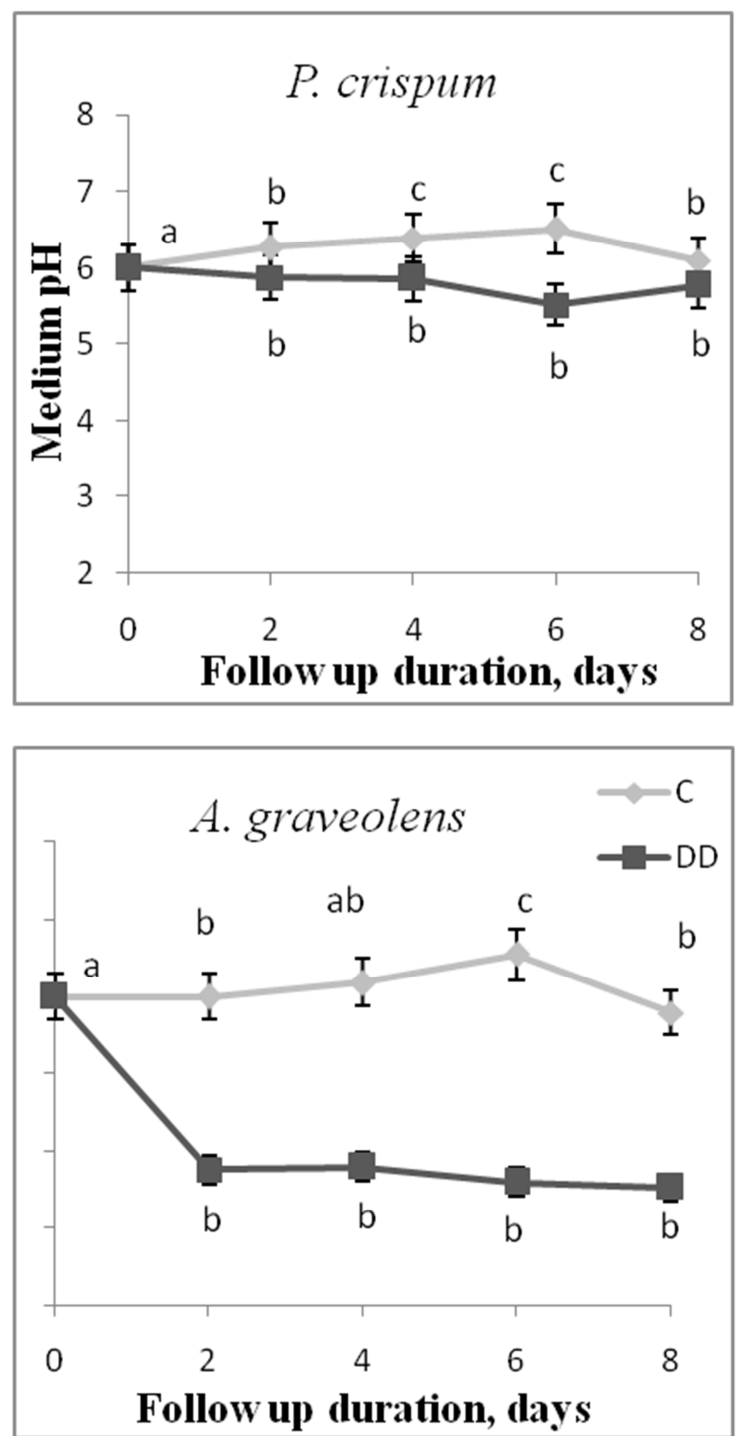

Figure 3. Changes in nutrient solution $\mathrm{pH}$ of control and deficient plant during the treatment period. Values are means of 8 replicates \pm standard deviation. Different letters correspond to significantly different values at $P<0.05$.

\subsection{Nutrient Status}

Iron content was remarkably greater in the Fe-sufficient plants as compared to that of Fe-deficient ones, for both species (Table 2). The sharpest decline of its concentration was recorded in roots of $P$. crispum, in which the reduction rate reached $56 \%$, while it was less pronounced in $A$. graveolens, reaching 38\% (Table 2).

No significant accumulation was detected for $\mathrm{Zn}$ in stems of $P$. crispum and A. graveolens cultivated under $\mathrm{Fe}$ starvation conditions, as compared to the control. However, leaves $\mathrm{Zn}$ content was noticeably increased for both species. This level was doubled in $A$. graveloens and enhanced to reach $85 \%$ in $P$. crispum. In addition, an increase of $30 \%$ was recorded in $P$. crispum roots cultivated under iron deficiency conditions (Table 2).

As shown in table 2, no significant accumulation was detected for $\mathrm{Cu}$ content in leaves and stems for both species cultivated under iron deficiency. However, an increase of $27 \%$ was registered in $P$. crispum roots (Table 2 ).

Table 2. Iron, Zinc and Copper concentration $\left(\mu g g^{-1} D W\right)$ in shoots and roots of $P$. crispum and A. graveolens plants grown for one month under iron-sufficient (C: control) or iron-deficient medium (DD: direct deficiency).

\begin{tabular}{lllll}
\hline Species & P. crispum & \multicolumn{3}{l}{ A. graveolens } \\
\hline Treatments & C & DD & C & DD \\
\hline & Fe & & & \\
Leaves & $6.99 \pm 0.83^{\mathrm{b}}$ & $3.52 \pm 0.35^{\mathrm{a}}$ & $4.35 \pm 0.43^{\mathrm{b}}$ & $2.86 \pm 0.39^{\mathrm{a}}$ \\
Stems & $4.08 \pm 1.1^{\mathrm{a}}$ & $2.23 \pm 1.2^{\mathrm{b}}$ & $3.73 \pm 0.91^{\mathrm{b}}$ & $2.49 \pm 0.43^{\mathrm{a}}$ \\
Roots & $11.63 \pm 2.84^{\mathrm{b}}$ & $5.06 \pm 0.98^{\mathrm{a}}$ & $9.55 \pm 3.02^{\mathrm{a}}$ & $5.89 \pm 0.38^{\mathrm{a}}$ \\
& $\mathrm{Zn}$ & & & \\
Leaves & $1.7 \pm 0.19^{\mathrm{a}}$ & $3.16 \pm 0.61^{\mathrm{b}}$ & $1.12 \pm 0.68^{\mathrm{a}}$ & $2.24 \pm 0.15^{\mathrm{b}}$ \\
Stems & $1.88 \pm 1.36^{\mathrm{a}}$ & $1.66 \pm 0.34^{\mathrm{a}}$ & $1.22 \pm 0.41^{\mathrm{a}}$ & $0.962 \pm 0.20^{\mathrm{a}}$ \\
Roots & $1.67 \pm 0.20^{\mathrm{a}}$ & $2.17 \pm 0.58^{\mathrm{b}}$ & $1.19 \pm 0.15^{\mathrm{a}}$ & $1.18 \pm 0.17^{\mathrm{a}}$ \\
& $\mathrm{Cu}$ & & & \\
Leaves & $0.655 \pm 0.15^{\mathrm{a}}$ & $0.657 \pm 0.33^{\mathrm{a}}$ & $0.27 \pm 0.17^{\mathrm{a}}$ & $0.235 \pm 0.17^{\mathrm{a}}$ \\
Stems & $1.06 \pm 1.45^{\mathrm{a}}$ & $0.355 \pm 0.16^{\mathrm{b}}$ & $0.297 \pm 0.05^{\mathrm{a}}$ & $0.17 \pm 0.149^{\mathrm{a}}$ \\
Roots & $1.49 \pm 0.80^{\mathrm{a}}$ & $1.90 \pm 0.43^{\mathrm{ab}}$ & $11.73 \pm 22.26^{\mathrm{a}}$ & $4.84 \pm 1.21^{\mathrm{b}}$ \\
\hline
\end{tabular}

Values are means of $4 \pm$ S.D. Different letters correspond to significantly different values at $(\mathrm{p}<0.05)$ according to Duncan test.

\section{Discussion}

The results of this work showed that Fe deficiency decreased significantly the plant growth activity, including shoot and root dry weight, shoot length and leaf number. This finding is in agreement with other researches [1, 12-13, 14, 15]. The observed decline was more severe in P. crispum Fe deficient plants, compared to A. graveolens. However, root length of deficient plants was increased, especially in $A$. graveolens which showed its relative higher capacity to bear the Fe stress. Such behaviour is characteristic for tolerant genotypes [16], and can be considered as the expression of a very distinct mechanism of regulation of iron uptake increasing both the external and internal root surface [17]. The various morphological and physiological changes in the root are thought to play an important role in the uptake of iron by raising the number of bittding sites [18].

The monitoring of plant morphological aspects, showed 
high chlorosis score in deficient plants, which is attested by a large decrease in chlorophyll content. Such symptoms give an idea about the differential behaviour of genotypes to $\mathrm{Fe}$ deprivation [19]. As shown above, A. graveolens was more able to maintain greater chlorophyll content compared to $P$. crispum, suggesting that the latter is more sensitive to $\mathrm{Fe}$ chlorosis. Fe shortage was also shown to decrease chlorophyll level in other species such as in chickpea [20], in pea [21] and in grapevine [22]. Indeed, iron is an essential micronutrient for several steps in photosynthetic pigment metabolism and chloroplast ultrastructure [23]. Up to $80 \%$ of the cellular iron in leaf cells is found in chloroplast [24-25]. Consequently, iron chlorosis is due to a reduction in chlorophyll synthesis, possibly because the enzyme catalyzing the biosynthesis step between $\mathrm{Mg}$-protoporphyrin IX monomethyl ester and protochlorophyllide requires two iron atoms [26-27]. Also, it could be the consequence of the proteolytic loss of photosynthetic components, including both photosystems and the cyt b6/f complex [28]. Furthermore, in response to iron deficiency, chloroplast proteome composition is modified, the amount of proteins involved in carbon fixation increase, whereas proteins from electron transfer complexes decrease [29].

With regard to the root acidification capacity, $A$. graveolens showed an important capacity to decrease the culture medium $\mathrm{pH}$ (Figure 3). Acidification of the rhizosphere serves to drive more iron into solution. Presumably, a proton ATPase pumps protons across the plasma membrane in response to iron limitation [30]. Thus, several authors suggested this parameter as a useful trait for screening tolerant genotypes to Fe deficiency [31, 32, 33]. In this context, Grotz and Guerinot [34] reported that releasing protons by Strategy I plants into the surrounding rhizosphere via a proton-ATPase serves to lower the $\mathrm{pH}$ of the rhizosphere, thereby increasing the amount of free soluble Fe (III), and to establish an electrochemical gradient that provides the driving force for the transport of $\mathrm{Fe}$ into the root. Our finding confirms that A. graveolens is more effective in overcoming this nutritional constraint than $P$. crispum.

Iron deficiency has been generally reported to affect mineral element homeostasis [35]. In this study, Fe content was decreased in all plant parts of the two species, cultivated under Fe-deficient conditions. Interestingly, the detrimental effect of iron shortage was more pronounced in the less tolerant species. These results are similar to those found by Mahmoudi et al. [20] in chickpea and by Jelali et al. [36] in pea. In addition, our results showed significant effect of $\mathrm{Fe}$ deficiency on the $\mathrm{Zn}$ concentration in leaves of both species. This result may be explained by the fact that $\mathrm{Zn}$ and $\mathrm{Fe}$ elements have the same transporters. With this regard, it was reported that there is no specificity for the transporters of heavy metals, thus they are able to assimilate any trace element [37]. Similarly, Cohen et al. [38] revealed an increasing of root $\mathrm{Zn}$ content under $\mathrm{Fe}$ deficiency in pea plants. Furthermore, an increase in $\mathrm{Cu}$ content was registered in roots of $P$. crispum. In this connexion, several researches showed that the mobilization of $\mathrm{Cu}$ and $\mathrm{Zn}$ in calcareous soils increased under iron deficiency conditions [39-40].

\section{Conclusion}

The present work demonstrates that two apiaceae species differ in their responses to iron deficiency. The tolerance of A. graveolens is due to its ability to preserve adequate chlorophyll content, to maintain plant growth and to acidify efficiently the culture medium, leading a better iron remobilization from roots to shoots. Such parameters could be then used in screening programs for the selection of new Fe-efficient genotypes. Future research should be directed towards the biochemical and molecular responses when plants are iron shortage conditions.

\section{Acknowledgements}

We would like to thank the Higher Institute of Agronomy of Chott Meriem for their financial support.

\section{Conflict of Interest}

The authors have not declared any conflict of interests.

\section{References}

[1] G. Zocchi, P. De Nisi, M. Dell'Orto, L. Espen, P. M. Gallina, Iron deficiency differently effects metabolic responses in soybean roots. J Exp Bot 58 (2007) 993-1000.

[2] G. Zocchi, S. Cocucci, Fe uptake mechanism in Fe-efficient cucumber roots. Plant Physiology 92 (1990) 908-911.

[3] S. Donnini, A. Castagna, A. Ranieri, G. Zocchi, Differential responses in pear and quince genotypes induced by $\mathrm{Fe}$ deficiency and bicarbonate. Journal of Plant Physiology 166 (2009) 1181-1193.

[4] V. Fernandez, V. Del Rio, J. Abadia, A. Abadia, Foliar iron fertilization of Peach (Prunuspersica (L.) Batsch): effects of iron compounds, surfactants and other adjuvants. Plant Soil 289 (2006) 239-252.

[5] P. R. Ortiz, B. C. Meza, F. R. De la Garza Requena, G. M. Flores, J. E. Barra, Evaluation of different iron compounds in chlorotic Italian lemon trees (Citrus lemon). Plant Physiol. Biochem. 45 (2007) 330-334.

[6] V. Fernandez, G. Ebert, Foliar iron fertilization-a critical review. J. Plant Nutr. 28 (2005) 2113-2124.

[7] D. R. Hoagland, D. I. Arnon, The water culture method for growing plants without soil. Circ 347. Calif. Agric. Exp. Sta, BerkleyCalif, 1950, pp. 32.

[8] L. Jacobson, Maintenance of iron supply in nutrient solutions by a single addition of ferric-potassium ethylene diaminetetracetate. Plant Physiol. 26 (1951) 411-413.

[9] R. R. Gildersleeve, W. R. Ocumpaugh, Greenhouse evaluation of subterranean clover species for susceptibility to iron deficiency chlorosis. Crop Science 29 (1989) 949-951. 
[10] A. Torrecillas, A. Léon, F. Del Amor, M. C. MartinezMompean, Determinacion rapida de clorofila en discos foliares de limonero. Fruits 39 (1984) 617-622.

[11] W. Zorrig, A. Rouached, Z. Shahzad, C. Abdelly, J. C. Davidian, P. Berthomieu, Identification of three relationships linking cadmium accumulation to cadmium tolerance and zinc and citrate accumulation in lettuce. Journal of Plant Physiology 167 (2010) 1239-1247.

[12] H. Houmani, N. Jelali, C. Abdelly, M. Gharsalli, Mineral elements bioavailability in the halophyte species Suaedafruticosa. Journal of Biological Research-Thessaloniki 17 (2012) 113-120.

[13] W. M'sehli, M. Dell'Orto, P. De Nisi, S. Donnini, C. Abdelly, G. Zocchi, M. Gharsalli, Responses of two ecotypes of Medicagociliaris to direct and bicarbonate-induced iron deficiency conditions. ActaPhysiol Plant 31 (2009) 667-673.

[14] A. Molassiotis, G. Tanou, G. Diamantidis, A. Patakas, The rios Effects of 4-month $\mathrm{Fe}$ deficiency exposure on $\mathrm{Fe}$ reduction mechanism, photosynthetic gas exchange, chlorophyll fluorescence and antioxidant defense in two peach rootstocks differing in $\mathrm{Fe}$ deficiency tolerance. J. Plant Physiol. 163 (2006) 176-185.

[15] R. Ksouri, A. Debez, H. Mahmoudi, Z. Ouerghi, M. Gharsalli, M. Lachaal, Genotypic variability within Tunisian grapevine varieties (Vitisvinifera L.) facing bicarboante-induced iron deficiency. Plant PhysiolBiochem 45 (2007) 315-322.

[16] M. Pestana, A. De Varennes, J. Abadia, E. A. Faria, Differential tolerance to iron deficiency of citrus rootstocks grown in nutrient solution. Sci. Hortic. 104 (2005) 25-36.

[17] D. Kramer, V. Romheld, E. Landsberg, H. Marschner, Induction of transfer-cell-formation by iron deficiency $\mathrm{m}$ the root epidermis of Helianthus annuus L. Planta 147 (1980) 335-339.

[18] B. E. S. Gunning, J. S. Pate, L. G. Briatry, Specialized transfer cells in minor veins of leaves and their possible significance in phloem translocation. J. Cell Biol. 37 (1968) C7-C12.

[19] Sudahono, D. H. Byrne, R. E. Rouse, Greenhouse screening of citrus rootstock for tolerance to bicarbonate-induced iron chlorosis. Hortscience 29 (1994) 113-116.

[20] H. Mahmoudi, N. Labidi, R. Ksouri, M. Gharsalli, C. Abdelly, Differential tolerance to iron deficiency of chickpea varieties and Fe resupply effects. C. R. Biologies 330 (2007) 237-246.

[21] N. Jelali, M. Dell'Orto, M. Rabhi, G. Zocchi, C. Abdelly, M. Gharsalli, Physiological and biochemical responses for two cultivars of Pisumsativum ("Merveille de Kelvedon" and "Lincoln") to iron deficiency conditions. ScientiaHorticulturae 124 (2010) 116-121.

[22] L. Bavaresco, M. Fregoni, A. Perino, Physiological aspects of lime-induced chlorosis in some Vitis species. I. Pot trial on calcareous soil. Vitis 33 (1994) 123-126.

[23] J. F. Briat, I. Fobis-Loisy, N. Grignon, S. Lobréaux, N. Pascal, G. Savino, S. Thoiron, N. Von Wirén, O. Van Wuytswinkel, Cellular and molecular aspects of iron metabolism in plant. Biology of the cell 84 (1995) 69-81.

[24] N. Terry, J. Abadia, Function of iron in chloroplast. J. plant Nutr. 9 (1986) 609-646.

[25] R. Hänsch, R. R. Mendel, Physiological functions of mineral micronutrients $(\mathrm{Cu}, \mathrm{Zn}, \mathrm{Mn}, \mathrm{Fe}, \mathrm{Ni}, \mathrm{Mo}, \mathrm{B}, \mathrm{Cl})$. Current Opinion in Plant Biology 12 (2009) 259-266.
[26] J. Moseley, J. Quinn, M. Eriksson, S. Merchant, The Crd1 gene encodes a putative di-iron enzyme required for photosystem I accumulation in copper deficiency and hypoxia in Chlamydomonasreinhardtii. The EMBO Journal 19 (2000) 2139-2151.

[27] S. Tottey, M. A. Block, M. Allen, T. Westergren, C. Albrieux, H. V. Scheller, S. Merchant, P. E. Jensen, Arabidopsis CHL27, located in both envelope and thylakoid membranes, is required for the synthesis of protochlorophyllide. PNAS 100 (2003) 16119-16124.

[28] J. F. Briat, C. Curie, F. Gaymard, Iron utilization and metabolism in plants. Current Opinion of Plant Biology 10 (2007) 276-282.

[29] S. Andaluz, A. F. Lopez-Millan, J. De las Rivas, E. M. Aro, J. Abadia, A. Abadia, Proteomic profiles of thylakoid membranes and changes in response to iron deficiency. Photosynthesis Research89 (2006) 141-155.

[30] J. Jeong, E. L. Connolly, Iron uptake mechanisms in plants: functions of the FRO family of ferric reductases. Plant science 176 (2009) 709-714.

[31] M. Dell'Orto, S. Santi, P. De Nisi, S. Cesco, Z. Varanini, G. Zocchi, R. Pinton, Development of Fe-deficiency responses in cucumber (Cucumissativus L.) roots: involvement of plasma membrane H+-ATPase activity. Journal of Experimental Botany 51 (2000) 695-701.

[32] R. Ksouri, S. M'rah, M. Gharsalli, M. Lachâal, Biochemical responses to true and bicarbonate-induced iron deficiency in grapevine (Vitis) genotypes. J. Plant Nutr. 29 (2006) 305-315.

[33] M. Rabhi, Z. Barhoumi, R. Ksouri, C. Abdelly, M. Gharsalli, Interactive effects of salinity and iron deficiency in Medicagociliaris. C. R. Biologies 330 (2007) 779-788.

[34] N. Grotz, M. L. Guerinot, Limiting nutrients: an old problem with new solutions? Current Opinion in Plant Biology 5 (2002) 158-163.

[35] R. M. Welch, W. A. Norvell, Growth and nutrient uptake by barley (Hordeumvulgare L. cv Herta): studies using an N-(2hydroxyethyl)ethylenedinitrilotriacetic acid-buffered nutrient solution technique. II. Role of zinc in the uptake and root leakage of mineral nutrients. Plant Physiology, 101 (1993) 627-631.

[36] N. Jelali, I. Ben Salah, W. M'sehli, S. Donnini, G. Zocchi, M. Gharsalli, Comparison of three pea cultivars (Pisumsativum) regarding their responses to direct and bicarbonate-induced iron deficiency. ScientiaHorticulturae 129 (2011) 548-553.

[37] E. Lombi, K. L. Tearall, J. R. Howarth, F. J. Zhao, M. J. Hawkesford, S. P. Mcgrath, Influence of iron status an cadmium and zinc uptake by different ecotypes of the hyper accumulator Thlaspicaerulescens. Plant Physiol. 128 (2002) $1359-1367$.

[38] C. K. Cohen, T. C. Fox, D. F. Garvin, L. V. Kochian, The role of iron deficiency stress responses in stimulating heavy-metal transport in plants. Plant Physiology 116 (1998) 1063-1072.

[39] M. Treeby, H. Marschner, V. Römheld, Mobilization of iron and other micronutrient cations from a calcareous soil by plant-borne, microbial, and synthetic metal chelators. Plant Soil 114 (1989) 217-226.

[40] F. J. Zhao, R. E. Hamon, M. J. McLaughlin, Root exudates of the hyperaccumulator Thlaspicaerulescensdo not enhance metal mobilization. New Phytologist 151 (2001) 613-620. 